\title{
Women in Need: Debt-Related Requests from Early Medieval Egypt ${ }^{2}$
}

In the pre-industrial rural world, micro-credit and agricultural credit were a structural element of everyday life, and have been studied for decades by historians and anthropologists, often offering very interesting insights on the respective societies they study. Debt as a social phenomenon, and its capacity to alter and structure social relations and hierarchies, has been noted by historians, sociologists, and anthropologists alike. Although the most common and obvious line of thought sees debt - rightly - as the first step into a downward spiral of impoverishment, much work has also emphasised the reverse aspect: its function as a safety net for the economically weak, a last-resort attempt to avoid being ejected from the social system. In L'économie morale: pauvreté, crédit et confiance dans l'Europe préindustrielle (2008), Laurence Fontaine broke new ground by linking the history of poverty and that of trust and social cohesion to the history of credit and the understanding of the hierarchies and networks that it both created and sustained. ${ }^{2}$ By seeing credit as a control mechanism of the economically powerful over the economically weak, but at the same time bringing out its role as a tool in the hands of those among the weak who were still trusted enough to borrow, Fontaine brought to light the double function of credit and debt as vectors of social bonds, but bonds that are necessarily unequal.

Building on this line of historiography, François Lerouxel's Le marché du crédit dans le monde romain (Egypte et Campanie) conducts a systematic study of credit in Roman Egypt. ${ }^{3}$ One of the things Lerouxel highlights is the importance of private credit and micro-credit alongside the institutional and large-scale operations studied until then, and their pervasive presence within communities and between individuals of all social levels. Contrary to the image given by literary texts, papyri unsurprisingly show that just like in pre-industrial Europe, rural society and agricultural practice were largely dependent on credit. The much higher proportion of women taking part in the private credit market has also been brought to light by Lerouxel. ${ }^{4}$

In early medieval Egypt these characteristics remained to a large extent unchanged. On the whole, the obvious common impression that credit is a form of exploitation, and debt a path to poverty are corroborated by the evidence from the period. ${ }^{5}$ Things however, are not as straightforward: the credit economy also functioned

1 The research for this article was generously funded by a Forschungsstipendium from the Gerda Henkel Stiftung, as part of a larger project on debt and dependence in late antique Egypt and Palestine.

2 Fontaine (2008); see also Fontaine (2001) and Fontaine (2010).

3 Lerouxel (2016).

4 Lerouxel (2006); for the later period, see Wilfong (1990); (2002); Papaconstantinou (2016b).

5 See the overview in Papaconstantinou (2016a). 
for some as a system of social inclusion which ultimately prolonged for them the ability of maintaining a social identity and a place within the community, which they would have lost without the possibility to borrow. This possibility, however, was not a given: it depended on the prospective borrower's capacity to command trust or offer some other form of guarantee, which meant mobilising networks of support. Thus, even the most miserable borrower was still better off than someone who could not borrow - but this came at the price of a relation of patronage and the resulting long-lasting dependence.

Several elements in the papyri show this mobilisation of networks in action. Perhaps the most obvious, which I have described elsewhere, was the practice of using guarantors to secure a loan. ${ }^{6}$ This was a relatively common practice: for the lender it could function as any other security, by making it possible to recover the debt at the end of the agreed period; for the borrower, however, it had an important - if shortterm - advantage, as it represented a security against losing a field, a house, or precious objects, because in case of default the guarantor would pay, and he simply became debtor to a new creditor. We see this for example with a certain Severus, son of Bane, who had borrowed 40 solidi/dinars from Anthony, son of Herakleides, headman of How (Diospolis Parva) and a deacon. In a document drawn up in Coptic and Arabic, Anthony agreed to make no further claims on Severus, because Muslim b. Bashshār of the city of Shmun (Hermopolis) had paid the sum for him. The document was intended as a security for the guarantor. ${ }^{7}$ This is also found in cases with much smaller sums, and there are indications that this could be prolonged with a second and even a third guarantor. ${ }^{8}$

Obtaining guarantors involved asking for a favour, and in documentary terms, one must assume that an informal letter requesting said favour preceded such a transaction - although the request may well have been oral in a number of cases. What one does find are letters written by patrons on behalf of prospective borrowers, asking that $\mathrm{X}$ should lend them money, and implicitly at least guaranteeing that loan. Thus in O.CrumVC 71, a certain Paipous asks a 'holy, pious father' to lend something to Paul, an act which he calls 'charity'. It is obvious from the letter that it is at least the second year in a row when this 'charity' is being made, and Paipous undertakes to repay the 'pious father' back for his advance.'

Networks were also useful at later stages of the credit cycle, namely once a debt had been contracted and one of the parties was in some form of difficulty. For instance, creditors would petition the authorities for help with the recovery of unpaid debts. More commonly, however, the requests for help come from debtors, and they are addressed to much lower levels of authority, in documents that are less formal than petitions.

6 Papaconstantinou (2016a) 626-629.

7 P.Ryl.Copt. 214 (first half of VIII)

8 Papaconstantinou (2016a) 627-628.

9 See the discussion in Papaconstantinou (2016a) 627. 
From the sixth century onwards, official petitions - i.e. documents drawn up by a lawyer on behalf of third parties and addressed to the secular authority of the area - had been evolving in ways that Jean-Luc Fournet's work on the archive of Dioscorus has highlighted and clarified. ${ }^{10}$ In particular, the prooimion (preamble) had developed quite extensively; it was structurally followed by a narratio or exposition of the facts, and then the request proper. Fournet has also shown that there was a clear perception of a distinction, in that period, between petitions and other documentary genres, to the point that a petition was not only written in a different way on the papyrus, but the papyrus piece itself was cut differently. Petitions were written parallel to the fibres, in long lines and careful writing, following the material form of literary texts, and to some extent letters, rather than legal and administrative documents.

In what follows I will take a closer look at five letters of request by five different women in the seventh- and eighth-century Theban region. All five are addressed to clerics, whose help is requested in solving a debt-related problem. What strikes one immediately when looking at these letters is that they lie on a continuum with the official petitions, but also from formal to informal: at one end, we have structured texts showing that there was a perceived irregularity making it conceivable for the petitioner to use 'the law' in support of a claim; at the other end are letters that ask very straightforwardly for a favour. In all five cases, the addressee is asked to intervene because of exceptional circumstances that have disrupted the author's life and capacity to pay off (or recover) the debt. The latter persuasion technique is, of course, also common in formal petitions, so that often what distinguishes letters asking non-official figures for favours and petitions to the authorities is the context in which they are used.

The first letter dates from ca. 630, immediately after the Persian occupation of the country, and it is written on both sides of an ostrakon, with two lines added on the bottom edge formed by the break of the sherd: ${ }^{11}$

First I embrace the sweetness of the holy feet of your truly God-loving fatherliness, which intercedes for us before God; and you are the one who beseeches God for the entire people and whom God has appointed true high priest to make petition for the whole people before God; and you are our patron who intercedes for us before God and men.

I am this wretched one, miserable beyond (all) men on earth, and greatly weighed down with grief and sadness, and heartbroken for my husband who is dead, and for my son whom the Persians beat (?) ... and my cattle which the Persians carried off.

Now, I beg you of your holy fatherliness to send and bring the headman of Jeme and Amos, and ask them to leave me in my house and not to have me wander abroad. For they said to me, "You are liable for the field."

The son, also, whom I had was heartbroken and took to flight.

And also the pair of cattle which were left from the Persians - the moneylender came forth and

10 See especially Fournet (2004), but also Fournet (1993); (1994); (2003).

11 SBKopt. I 295; transl. Bagnall/Cribiore (2006) 242. See also the ed. pr. in Drescher (1944). 
carried them off and sold them on account of his loan which I borrowed for the tax. Be so kind to me as for me to be settled in my house.

Verso - Give it to my lord father the holy [bishop] Pesente, from this poor wretched wife of the deceased Pesente.

The author remains nameless. She is a widow who had most of her cattle stolen by the Persians during their occupation of Egypt (619-629). The few animals they left behind were later taken by 'the moneylender'. Her son has fled, after being beaten by the Persians. She is writing to the bishop ('high priest') Pesente, asking him to intervene with the headman of Jeme so that she can keep her house, which is most probably mortgaged because of a loan she has taken to pay her taxes.

The addressee is almost certainly Pisenthios of Koptos/Qift, bishop from 599632. He came from the Theban region and had close links with the monasteries of the area. From what we know, he fled to the mountains above Jeme during the Persian occupation and waited until it ended before returning to his see. Part of his correspondence is preserved, and in course of re-publication. ${ }^{12}$ Apparently found at his place of refuge, it shows that he enjoyed quite some prestige in the area, as the biography written after his death also shows. Nothing makes this identity absolutely certain, but the request is not a simple one, since it involves property of some value, and therefore a relatively high potential loss for the lender: presumably only a prestigious individual could pull off such an intervention successfully.

The widow herself is not quite of the destitute sort: this was a family with sizeable cattle, and possessing a house. She is in this situation due to unforeseen circumstances: the death of her husband and the Persian invasion. She uses the pathos of her disenfranchisement - a reasonably established woman having suddenly, and through no fault of her own, found herself in dire circumstances - to solicit a favour which is clearly expressed as such. Nowhere does she hint that it is her right to obtain this, nor does she blame anyone in particular.

Despite being written on an ostrakon and presented as a letter, this is a very elaborate text with many of the characteristics of a formal petition. The length and style of the introductory statement are reminiscent of the long, flattering version of the prooimion familiar from sixth-century petitions. The rest of the text follows the model of a petition as well, albeit in a very summary way: the address and preamble are followed by a narratio or exposition of the facts, and then by the request itself. The bishop, however, is only addressed as an intercessor 'before God and men', not as a decision-maker: It is the headman of the village who will have the final say. ${ }^{13}$

12 Dekker (2011); see also van der Vliet (2002); (in press).

13 See the discussion in Papaconstantinou (in press); on intercession as a social practice in the Middle Ages, see the papers in Moeglin (2004). 
The second text is much less elaborate, and sent to a less elevated cleric. The author, Thello, is another widow in the same region, and she is writing to the monk Epiphanios in a monastic establishment of the Theban area. ${ }^{14}$

... your [father]liness (?), and I embrace the prints of the feet of your God-lovingness, my lord father. I, this servant (and) widow, Thello, (widow) of the deceased Peter, son of Plos, in the congregation of Ptene, inform your paternity - for it is you whom God has appointed to inquire concerning the affairs of the poor - for before the Persians came south, my deceased husband gave some grain to the priest of Apa Shenetom and Sakau, (son) of Joui, and they sowed it in the plain. They have not paid me anything for it until now. And look, I have paid them many a visit, saying "Write me (a note) for it, until the place is at peace and you can pay me a little yearly." They went to law, one with another, and it was decided that each one should write down his share. Look ...

The letter was written during the Persian occupation, as it describes the Persians having already come south, but the place not yet 'at peace'. Thello, who lives in a small village, is asking the head of a monastic community to ensure that the priest of a local shrine and another man will pay her back for the grain her late husband had lent them. This is an operation of much smaller scale, involving a loan in kind. The nature of the repayment is unclear, but even if it is money, the sum involved was not of the same level as that dealt with by Pesente. Thello's own social standing is clearly lower than that of Pesente's widow. Ironically, however, she is the lender, not the borrower, and not about to lose her house.

This letter also follows - much more loosely - the conventions of a petition: a short prooimion praising the recipient, followed by a narratio with the facts. The request proper certainly followed, but it is lost - although its content is not hard to guess. It is made to a monk with some local authority because he would certainly have had more weight and fewer inhibitions in dealing with shrine personnel.

The third letter is also from a woman to a monk. It raises yet a different problem - one that is not entirely clear because the document is damaged. ${ }^{15}$

I, Taouaou the daughter of Joachim, write to my father Zacharias:

At the time when Joachim came to settle, he received a pair of coverlets and a half-trimesion from Georgios. He deposited the ... as a pledge with him. Well, for two years he caught pigeons (there?). The first year, he caught 60 pair (?), the second year he caught 70 pair. He filled a ... I don't know how many he took. The third year, which is the current one, he came and took 10 pair. Be so kind as to ask him (?). If he does not ..., let him divide it with me, for I need it for my work.

I understand that Georgios lent a half-trimesion and some textiles to Joachim, who deposited a pledge for them. This pledge seems to have involved the right to use pigeons from Joachim's peristereōnas - pigeon farm. Taouaou clearly thinks he is abus-

14 O.Mon.Epiph. 300; transl. Bagnall/Cribiore (2006) 249.

15 O.Vind.Copt. 257 = O.CrumST 378; transl. Bagnall/Cribiore (2006) 311. 
ing this right of access, and asks Zacharias to do something so that they can come to a settlement. The precise circumstances are not clear, but they are less important here than the approach taken. The document is organised much more like a letter - in particular it has a typical epistolary address, then describes the facts without preliminary statements about the qualities of the recipient, and moves on to a request introduced with 'be so kind', a very characteristic request formula in letters. It is unclear why Joachim does not take this action himself: he may be absent - or possibly deceased, but then he would probably have been described as 'the late Joachim'. Again, a request for mediation is addressed to a monk. This can be pure coincidence, but can plausibly be explained by the higher authority a monk would have carried at the village level, especially compared to other individuals Taouaou might have asked.

A short incomplete letter by a certain Sarah to 'father' Ezekiel shows a very different, almost telegraphic style. ${ }^{16}$

This humblest Sarah writes to her lord father Ezekiel.

Now, I inform you that Paulos died. Although you were protecting him and my children, he still died. Look, your charity is poured out upon them until now. I inform you concerning this man that he seized me for a debt. He said, "What did you pay again ...?” Now, be so kind ... my priests ... go to the ...

Even though Ezekiel is Sarah's protector, her tone is firm and no-nonsense. Once again, a churchman is asked to intervene regarding a debt by a woman. As often in letters, the content is not very clear. A man has seized Sarah because of a debt, and it is tempting to relate this to the death of Paulos - whose relation to Sarah is not obvious, but mentioned as he is along with her children as being in Ezekiel's care, he must have been either her husband, or a member of her household or her immediate relations.

A final letter, more complete, but still not very clear, reveals another situation where a woman is in trouble because of a debt. ${ }^{17}$

Thanasia writes to her lord the priest Apa Ananias and Apa Bartholomaios.

Be so kind, since I left the village, three years ago now, the village scribe said to me, "Go north". I went. It happened that I came over to the village because I was in the vicinity. Now then, he has arrived. Be so kind as to ask him, "Why do you detain her?" Indeed, he said, "I wanted the deed of the house". I drew up the deed (?), but he did not take it, nor did he dissolve the surety. Be so kind as to ask and beg him about me. Indeed, I have paid except for a -. I gave it to you. Good health in the Lord, Ananias and Bartholomaios.

Thanasia is writing to two priests to ask for mediation with a man who has detained her, and has laid claim to her house because of a debt. She does not understand why

16 O.CrumST 233; transl. Bagnall/Cribiore (2006) 201.

17 O.Crum 133; transl. Bagnall/Cribiore (2006) 309. 
she is still detained, since he has drawn up the requested deed (presumably renouncing the house), but for some reason it was not accepted by the creditor who, along with Thanasia herself, also kept the surety document.

With the exception of the second one, these letters are among the many that contribute to the impression I mentioned at the beginning that contracting a debt could be the first step in a downward spiral both economically and socially. The 'legal plunder', to quote Daniel Lord Smail, ${ }^{18}$ that unpaid debts made possible could leave entire sections of the population indigent and dependent. It is true that for the economically weakest, the possibility to borrow, if only to pay the poll tax, could allow individuals to avoid incarceration by the authorities, even if this came at the price of a different form of debt, or even one's free status. The cases I chose above are rather different. Of the five women, three certainly had some property - two had houses, and a third one had at least a field with a pigeon-farm; one was affluent enough to lend seed to two different people; only 'the humblest Sarah' could have been entirely penniless. For all, including perhaps Sarah, the reason for their troubles seems to be the absence - through death or for some other reason - of a male relative. In the first case, the author is in difficulty because of the exceptional circumstances of the Persian invasion, which has entirely destroyed her otherwise rather cosy economic setup: she has lost both the assets and the labourers that could provide an income, and is therefore unable to pay a debt which in another situation could have proved straightforward. Despite the lack of detail, and the subjectivity of the letters, in the other four cases the men involved seem to be abusing their power over women who were left without male protectors. The monks and clerics to whom these women are appealing are not only figures with symbolic capital: they are also the most obvious male members of the community to whom women can go for help in such circumstances.

The weakness and helplessness implied in the self-description as a widow had long been a rhetorical topos in documents whose aim was to obtain justice or a favour. ${ }^{19}$ It is implicitly present in the letters above, through the insistence on the woes suffered in the absence of a man, intended to elicit the pity of the recipient. Predictably, the first letter is the only one with a proper rhetorical flight on that theme: 'I am this wretched one, miserable beyond all people on earth, and greatly weighed down with grief and sadness, and heartbroken for my husband who is dead, and for my son...' Petitionary forms will very naturally contain affective rhetoric, which gives a strong impression of access to the individual in a way more stereotyped documents

18 Smail (2016).

19 Beaucamp (1985) 150-151. 
do not. So, can we say that we can hear, with these letters, the distant voices of seventh-century Upper Egyptian women? ${ }^{20}$

In 2008, in an article entitled 'Tormented Voices', James Keenan discussed P.Cair.Masp. I 67002, a long petition by Dioscorus and the 'wretched peasants' of Aphrodito to the duke of the Thebaid Athanasios, detailing in minute detail the exactions and ill-treatment they have suffered at the hands of the pagarch Menas. ${ }^{21}$ Keenan's title was directly borrowed from Thomas Bisson's now classic Tormented Voices: Power, Crisis and Humanity in Rural Catalonia 1140-1200, which analyses 16 uninventoried documents from the rich archives of twelfth-century Barcelona. ${ }^{22}$ The content of those documents is indeed highly comparable to a number of late antique petitions filed by rural inhabitants against the powerful of the region: The peasants accuse the pagarch of extorting much more money from them than he should have through torture, seizure, destruction of houses and even blocking the irrigation canals in order to force them to submit.

After a summary of the petition's contents, Keenan discusses its length, the tax terminology it contains, the consciousness of time in the narrative, and the rare, sometimes poetic terms used for some rather mundane realities. The discussion served to introduce Keenan's doubts about the paternity of the 'tormented voices': although the petition is cast in the first person plural, purporting to 'represent the communal "voice" of the afflicted villagers', it is clear that those villagers 'are "speaking" through the pen of an accomplished notary with poetic ambitions who knows all the proper formulas and then some'. ${ }^{23}$ Keenan goes on to draw the striking parallels between P.Cair.Masp. I 67002 and Bisson's memorials of complaint: their content, the procedures by which they came to be, the social realities they imply, and, crucially, the methodological issues they raise, in particular with respect to the nature of the 'voices' we are accessing through such documents.

Recent work on petitions in the early modern and modern world shows the extent to which individual voices, even when oral and written are by the same person, will always be mediated through the filter of rhetorical and compositional models. ${ }^{24}$ They follow what linguistic anthropologists call genre. ${ }^{25}$ Like literary genre, everyday linguistic genre is what allows individuals sharing the same cultural background to recognise a given style in speech situations (or written texts), which sets in motion certain specific expectations. For example, a framing device such as 'Once upon a time' will carry with it a set of expectations concerning the further unfolding of the discourse, indexing other texts initiated by this opening formula. This cultur-

20 The question is discussed in the introduction of Bagnall/Cribiore (2006) 6-8, but with the accent on who wrote the letters rather than whose words - or voice - they transmit.

21 Keenan (2008).

22 Bisson (1998).

23 Keenan (2008) 178.

24 See for instance Grama (2010); Zaret (1996); (2000).

25 See Baumann (2000) with further references. 
al/linguistic genre is what we can see at work the petitions written by Dioscorus, or by other notaries like him: whatever the improvements made to the form or vocabulary, he shared the cultural expectations of the 'voices' he mediated.

Even though the letters written by our five women do not qualify as petitions, but, as mentioned above, sit at different points of a continuum between petition and informal letter, the question can easily be transferred to them. Indeed, as Fournet has shown in some detail, these two types of document have a common foundation, a petition being, ultimately, a specific, formal, and stylised version of a letter.

Taken together, these texts, addressed to figures of authority, all use the same argumentative repertoire (need for protection, dependence on men, victimisation, helplessness), whose gendered character is evident - most explicitly in the first text. ${ }^{26}$ Similarly to petitions, this arguably stems from a cultural expectation dictating a specific genre in the formulation of female requests. This presupposes a certain level of cultural education or, to put it in different terms, a familiarity with precedent and the norms of procedure, a knowledge of the generic forms that were the norm in similar circumstances. Whether these letters were actually written by the women themselves or by a man writing for them, those generic elements would be largely the same if adherence to cultural norms was high - and that is probably why we have so much difficulty telling the difference.

Taken separately, the texts display within the same matrix a gradation, from those placing greater insistence on the rhetorical niceties and greater generic consciousness (in the first letter and even to some extent the second one) to those exhibiting a much more direct approach (the other three letters). This gradation was a function of the nature of the document (degree of resemblance to a petition), of the nature of the relation with the recipient (more or less direct), and of the degree of competence of the individual writing the document.

On the whole, it is possible to make a number of concluding remarks. The texts analysed confirm the importance taken by relations of patronage and protection in the functioning of the credit economy, and the role churchmen could take within that system. Despite the differences in documentary form, the requests made to patrons all mobilise the same linguistic genre, albeit at different degrees of intensity. An important factor in the definition of that genre are its gendered tropes: the 'tormented voices' of these Upper Egyptian women fulfil the cultural expectation, without revealing whether they have been materially put to paper by them or by a male amanuensis. Ultimately, the appeal to churchmen in letters adopting this gendered genre was a formula for the success or at least the efficiency of the request.

26 For formal petitions, see the analysis in Kotsifou (2012); Bagnall (2004) studies their evolution over time in late antiquity. 


\section{Bibliography}

Bagnall (2004): Roger S. Bagnall, “Women's petitions in late antique Egypt”, in: Denis Feissel and Jean Gascou (eds.), La pétition à Byzance (Monographies du Centre de recherche d'Histoire et Civilisation de Byzance 14), Paris, 53-60.

Bagnall/Cribiore (2006): Roger S. Bagnall and Raffaella Cribiore, Women's Letters from Ancient Egypt, 300 BC-AD 800, Ann Arbor.

Baumann (2000): Richard Baumann, "Genre”, in: Journal of Linguistic Anthropology 9, 84-87.

Beaucamp (1985): Joëlle Beaucamp, “La référence au veuvage dans les papyrus byzantins”, in: Pallas 32, 149-157.

Bisson (1998): Thomas Bisson, Tormented Voices. Power, Crisis and Humanity in Rural Catalonia 1140-1200, Cambridge, MA.

Dekker (2011): Renate Dekker, "Reconstructing and re-editing the archive of Bishop Pesynthios of Koptos/Keft ( $7^{\text {th }}$ century)", in: Current Research in Egyptology, Leiden 2010, Oxford, 33-41.

Drescher (1944): John Drescher, “A widow's petition”, in: Bulletin de la Société d’Archéologie Copte 10, 91-96, pl. I-II.

Fontaine (2001): Laurence Fontaine, "Antonio and Shylock. Credit and trust in France, c. 1680-1780", in: Economic History Review 54, 39-57.

Fontaine (2008): Laurence Fontaine, L'économie morale. Pauvreté, crédit et confiance dans l'Europe préindustrielle (NRF essays), Paris.

Fontaine (2010): Laurence Fontaine, "La dette comme signe d'appartenance dans l'Europe des XVII et XVIII' siècles", in: Finance et bien commun 37-38, 28-44.

Fournet (1993): Jean-Luc Fournet, "À propos de SB XIV 11856 ou quand la poésie rencontre le document”, in: Bulletin de l'Institut Français d'Archéologie Orientale 93, 223-235.

Fournet (1994): Jean-Luc Fournet, “L'influence des usages littéraires sur l'écriture des documents: perspectives", in: Proceedings of the 20th International Congress of Papyrologists, Copenhagen, 418-422.

Fournet (2003): Jean-Luc Fournet, "Between literary tradition and cultural change. The poetic and documentary production of Dioscorus of Aphrodite", in: Alasdair A. MacDonald, Michael W. Tomney, and Gerrit J. Reinink (eds.), Learned Antiquity. Scholarship and Society in the Near-East, the Greco-Roman World, and the Early Medieval West (Groningen Studies in Cultural Change 5), Leuven, 101-114.

Fournet (2004): Jean-Luc Fournet, “Entre document et littérature. La pétition dans l'Antiquité tardive”, in: Denis Feissel and Jean Gascou (eds.), La pétition à Byzance (Monographies du Centre de recherche d'Histoire et Civilisation de Byzance 14), Paris, 61-74.

Grama (2010): Emmanuela Grama, "Work, state, and the linguistic construction of 'self' in Romania of the 1950s and 1960s. A case study", in: Romanian Journal of Society and Politics 5, 38-64.

Keenan (2008): James G. Keenan, “'Tormented Voices.' P.Cair.Masp. I 67002”, in: Jean-Luc Fournet and Caroline Magdelaine (eds.), Les archives de Dioscore d'Aphrodité cent ans après leur découverte. Histoire et culture dans l'Égypte Byzantine. Actes du colloque de Strasbourg (8-10 décembre 2005) (Collections de l'Université Marc Bloch - Strasbourg; Études d'archéologie et d'histoire ancienne), Paris, 171-180.

Kotsifou (2012): Chrysi Kotsifou, "A glimpse into the world of petitions. The case of Aurelia Artemis and her orphaned children", in: Angelos Chaniotis (ed.), Unveiling Emotions. Sources and Methods for the Study of Emotions in the Greek World (Heidelberger althistorische Beiträge und epigraphische Studien 55), Stuttgart, 317-327.

Lerouxel (2006): François Lerouxel, “Les femmes sur le marché du crédit en Égypte romaine (30 avant J.C.-284 après J.-C.)”, in: Cahiers du Centre de recherches historiques 37, 121-136. 
Lerouxel (2016): François Lerouxel, Le marché du crédit dans le monde romain (Egypte et Campanie) (Bibliothèque des Ecoles Française d'Athènes et de Rome 374), Rome.

Moeglin (2004): Jean-Marie Moeglin (ed.), L'intercession du moyen âge à l'époque moderne. Autour d'une pratique sociale (Ecole pratique des hautes études - Sciences historiques et philologiques 5: Hautes études médiévales et modernes 87), Geneva.

Papaconstantinou (2016a): Arietta Papaconstantinou, "Credit, debt, and dependence in early Islamic Egypt and southern Palestine", in: Jean-Luc Fournet and Arietta Papaconstantinou (eds.), Mélanges Jean Gascou. Textes et études papyrologiques (P.Gascou) (Travaux et mémoires 20.1), Paris, 613-642.

Papaconstantinou (2016b): Arietta Papaconstantinou, “'Choses de femme’ et accès au crédit dans l'Égypte rurale sous les Omeyyades”, in: Olivier Delouis, Sophie Métivier, and Paule Pagès (eds.), Le saint, le moine et le paysan. Mélanges d'histoire byzantine offerts à Michel Kaplan (Byzantina Sorbonensia 29), Paris, 551-561.

Papaconstantinou (in press): Arietta Papaconstantinou, “'Great men,' churchmen, and the others. Forms of authority in the villages of the Umayyad Period”, in: Dominic Rathbone and Micaela Langelotti (eds.), Village Institutions in Egypt from Roman to Early Arab Rule, London.

Smail (2016): Daniel Lord Smail, Legal Plunder. Households and Debt Collection in Late Medieval Europe, Cambridge, MA.

van der Vliet (2002): Jacques van der Vliet: "Pisenthios de Coptos (569-632). Moine, évêque et saint. Autour d'une nouvelle édition de ses archives", in: Marie-Françoise Boussac (ed.), Autour de Coptos. Actes du colloque organisé au Musée des Beaux-Arts de Lyon, 17-18 mars 2000 (TOPOI Supplément 3), Lyon, 61-72.

van der Vliet (in press): Jacques van der Vliet, "A bishop and his flock. Saint Pesynthios of Koptos (569-632) and his networks", in: Proceedings of the Symposium on "Egypt in the Coptic Period" (Bibliotheca Alexandrina), Alexandria 2010.

Wilfong (1990): Terry Wilfong, "The archive of a family of moneylenders from Jême”, in: Bulletin of the American Society of Papyrology 27, 169-181.

Wilfong (2002): Terry Wilfong, Women of Jeme. Lives in a Coptic Town in Late Antique Egypt (New Texts from Ancient Cultures), Ann Arbor.

Zaret (1996): David Zaret, "Petitions and the 'invention' of public opinion in the English Revolution”, in: American Journal Sociology 101, 1497-1555.

Zaret (2000): David Zaret, Origins of Democratic Culture. Printing, Petitions, and the Public Sphere in Early Modern England (Princeton Studies in Cultural Sociology), Princeton. 
